\title{
総説
}

\section{Rheology of Silicone Rubbers}

by

Akira TAZAWA and Masamitsu TANIMURA

Toray Silicone Co., Ltd.

2-2 Chigusa-kaigan, Ichihara, Chiba 299-01

\section{シリコーンゴムのレオロジー}

\author{
田沢 晃・谷村 正満*
}

(原稿受理：1986年 9 月 8 日)

\section{1. 緒言}

シリコーンゴムが工業的に生産されるようになってから, 約 40 年になり, 最早, 新しい素忉とは言えなくなったが, 品質的な改良 を目指した新製品の開発活動は, 今な打活発であり, 次々に新し い用途を見いだして，工業的な地位を確固たるものにしつつある. これはいわゆる特殊ゴムの中にあっても, その特異な耐熱性, 耐酸化安定性, 耐候性, 低温柔軟性, 無毒性, 電気特性等が他の 有機系ゴムよりも優位であることと, 製造量の増加和よび生産合 理化によるコストダウンによって, コストノパーフォーマンスか ら見て割高感が薄れ，応用分野の裾野が画期的に広まったこと, 扣よび上記特性が省エネルギー, 省資源, 高信頼性, 安全衛生性 等の時代の要請に見事に合致していたことによるものと思われる.

このような用途拉よび製品の多様化は, 技術的にも新しい課題 を次々にもたらすこととなり, 物理強度の改善, 難燃性の付与, 耐油, 耐溶剈性の改良では目覚ましい成果を挙げ, また最近では, 繰り返し丕による疲学特性の改良等も可能となったが，技術的に 未解決の問題も多い.シリコーンゴムのレオロジーの問題もその 一つであり, 特に最近ではトータルコストダウンの意味から, 加 工時に和ける生産性改善がゴム加エメーカーの重大関心事となっ ているが，末硬化ゴムのレオロジー特性の制御については，研兑 例もほとんどなく，個々の問題について試行錯誤的に解決を計ら ざるを得ないのが現状である。

また用途面でも, 従来静的な応用分野が多かつたのに対し, 近 年では動的な使われ方が増加しており, 前記の耐疲労性のほか, 振動に刘する吸収特性の改善等も研究が緒についたばかりであり, 今後の課題となっているものである. 本総説は以上のような背景 を踏まえて, シリコーンゴムの特性を，主としてレオロジーを中 心に簡単に解説すると同時に, 実用的な観点から将来行われるべ き研究課題を提起することを目的としている。

*トーレシリューン(株) 勇299-01 市原市千種海岸 2-2
2. シリコーンポリマーの特性

シリコーンポリマーの中で最も簡単な構造をしているものは, ポリジメチルシロキサンであり, Fig. 1 亿示す方法で製造され ている. ポリマーの重合は酸または塩基性触媒によって進行し, 重合度の調整は末端形成能力のある一官能性シロキシ基や水等の 成分の量によって，任意行うことがでさる，実際にこの方法に よって低粘度オイルからガムまで製造されている。

有機ポリマーと比較した場合のシリコーンポリマーの特異な性 質は，骨格をなすシロキサン結合に由来している．ケイ素と同族

I 、直接法によるクロロシランの暂造

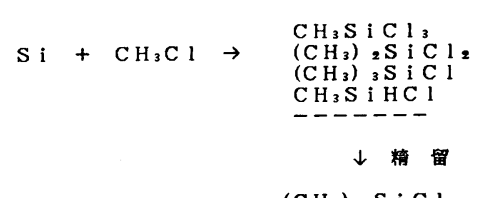

$\left(\mathrm{CH}_{3}\right)_{2} \mathrm{~S}$ i C 12

II. 加水分解によるオリコマーの造

$\left(\mathrm{CH}_{3}\right)_{2} \mathrm{SiCl}_{2}+2 \mathrm{H}_{2} \mathrm{O} \rightarrow\left(\mathrm{CH}_{3}\right)_{2} \mathrm{Si}(\mathrm{OH})_{2}+2 \mathrm{HCl}$

n $\left(\mathrm{CH}_{3}\right)_{2} \mathrm{Si}(\mathrm{OH})_{2} \rightarrow \mathrm{CH}_{3}$

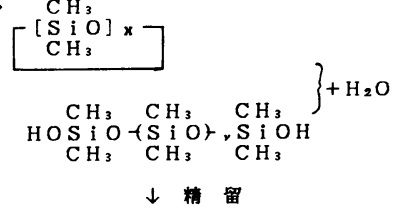

[ $\left(\mathrm{C}_{3}\right)_{2} \mathrm{~S}$ i O ] $x$

III. オリコマーの重合によるポリマーの慗造

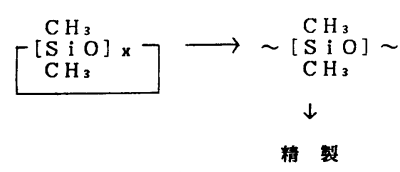

Fig. 1 Manufacturing process of polydimethylsiloxane. 
元素である炭亪と比較すると, 後者の価電子はL殼に属するのに 対し，前者はM款にあり，空の d 軌道の寄与を大きく受けること になる。例えば, $\mathrm{Si}-\mathrm{O}$ 結合距離は $1.64 \AA$ であり，有機ポリマ 一飞括ける C-C 結合距離 $1.54 \AA$ ，または $\mathrm{C}-\mathrm{O}$ 結合距離 $1.43 \AA$ よりも大きいものの，ケイ素と酸素の共有半径，またはイオン半 径の和として計算される結合距離よりも小さくなっている。 た, Si-O-Si の原子価角は $130^{\circ} \sim 160^{\circ}$ で, 正四面体角の $109^{\circ} 28^{\prime}$ よりもかなり大きく, やや直線的である。これらの事実は, $\mathrm{Si}-\mathrm{O}$ 結合の二重結合性を示唆するものと解釈されている. 一方, $\mathrm{Si}-\mathrm{O}$ の結合エネルギーは $106.3 \mathrm{kcal} / \mathrm{mol}$ であり, C-C 結合の $82.6 \mathrm{kcal} / \mathrm{mol}, \mathrm{C}-\mathrm{O}$ 結合の $85.5 \mathrm{kcal} / \mathrm{mol}$ と比較しはるかに大 きく，高い耐熱性を与えている，委た，ケイ素の電気陰性度は 1.90 (Pauling) であって, 炭素の2.55, 酸素の3.5よりる小さく, $\mathrm{Si}-\mathrm{O}$ 結合のイオン性は電気陰性度の差から $50 \%$ と計算される。 これらの特性は, シリコーンポリマー分子に大きな自由体積を与 え，分子鎖の自由回転を容易にし，柔軟で嵩高い特徵をもたらす ことになる．各結合軸回りの回転エネルギーを Table I に示す ${ }^{1)}$. 更にこのため, 分子間の凝集力は有機ポリマーよりもかなり小さ くなり, シリコーンゴムの場合には高い物理強度が得られにくい 理由にもなっている.

以上のことから，シリコーンポリマーのガラス転移温度は低い ことが予想される。事実, ポリジメチルシロキサンのガラス転移 温度は $-123^{\circ} \mathrm{C}$, 結晶化温度は $-40 \sim-50^{\circ} \mathrm{C}$ と非常に低く, 低温

Table I. Barriers of rotation ${ }^{1)}$

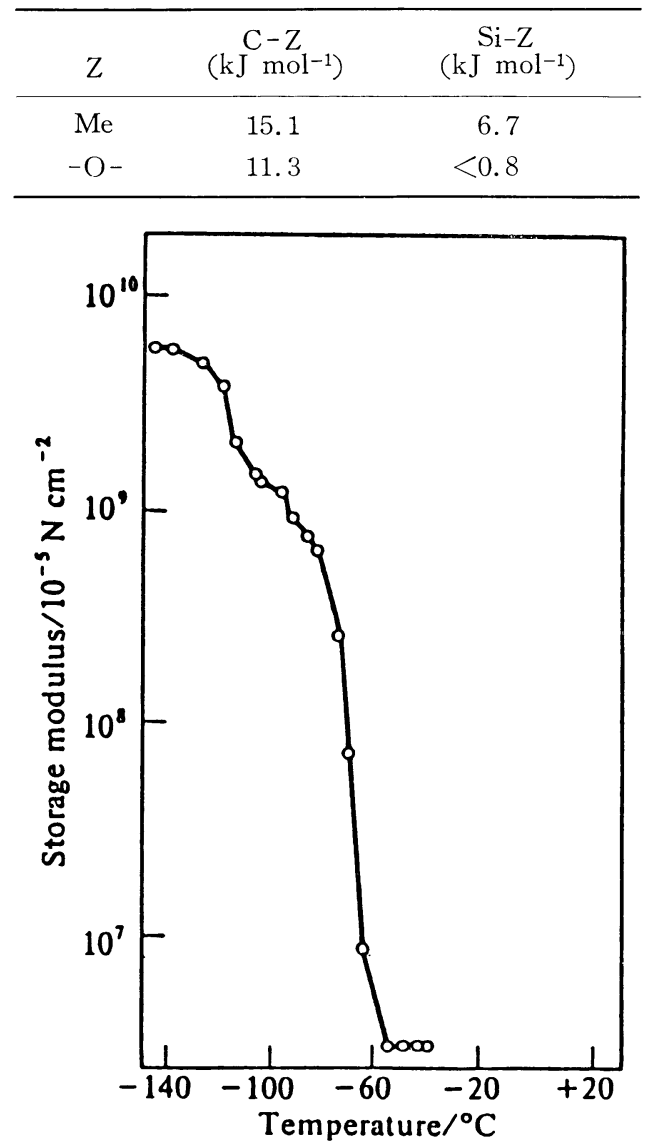

Fig. 2 Storage modulus of crosslinked polydimethylsiloxane evaluated using a torsion pendulum.2)
流動性が優れている. 架橋されたポリジメチルシロキサンでは, Fig. 2 に示すように, 結晶化温度付近で弾性率の急激な変化が 観察され，ゴムとしての耐寒限界と見なされる2). メチル基の代 りにフェニル基を導入すると，フェニル基含有量の增加とともに， ガラス転移温度は上䄯するが, 非常に少ない含有量で結晶化が妨 げられる領域があり，この領域では流動点が大幅に低下寸る ${ }^{33}$. この様子を Fig. 3 と Fig. 4 亿示す. このことを利用して, 脆 化温度が $-110^{\circ} \mathrm{C}$ の超低温用シリコーンゴムが実用化されてい る.

直鎖状ポリジメチルシロキサンの粘度と重量平均分子量の間に は，直線関係が認められて扣り，臨界分子量約 3 万以下では傾き 0.95，これ以上では 3.6 であり，一般的に直鎖状ポリマーに見ら れる経験則に一致している(4),5). Fig. 5 亿示す上5に, 臨界分子 量以下ではポリマー末端基の影響が現れ，シラノール基を持つポ リマーでは, トリメチルシロキシ末端の場合よりも粘度が高くな る。この影響は，分子内末端基間の相互作用によって，それ汪ど 大きくはならないとの報告もあるが6)，低分子量になるほど末端 構造の奇与が無視できなくなるのは間違いなかろう。ポリジメチ ルシロキサンの粘度は, 同一分子量の炭化水素系ポリマーよりも 低く, 温度依存性も小さい。

流動の活性化エネルギーは, Fig. 6 に示すように 3.4 ～ $3.8 \mathrm{kcal}$ とかなり低く，広範囲の分子量に対して注ぼ一定である7),8)。 た，ケイ素上の有機基がメチル以外のプロピル，トリフロロプロ

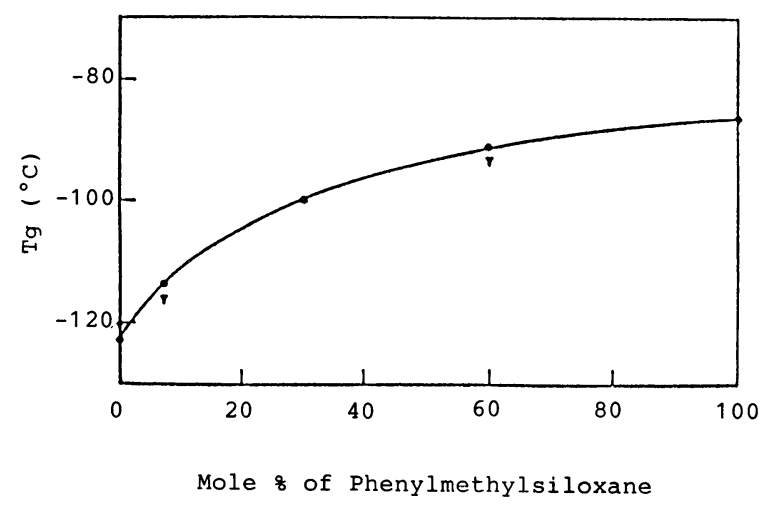

Fig. 3 Effect of phenylmethylsiloxane content on glass transition temperature. ${ }^{3)}$

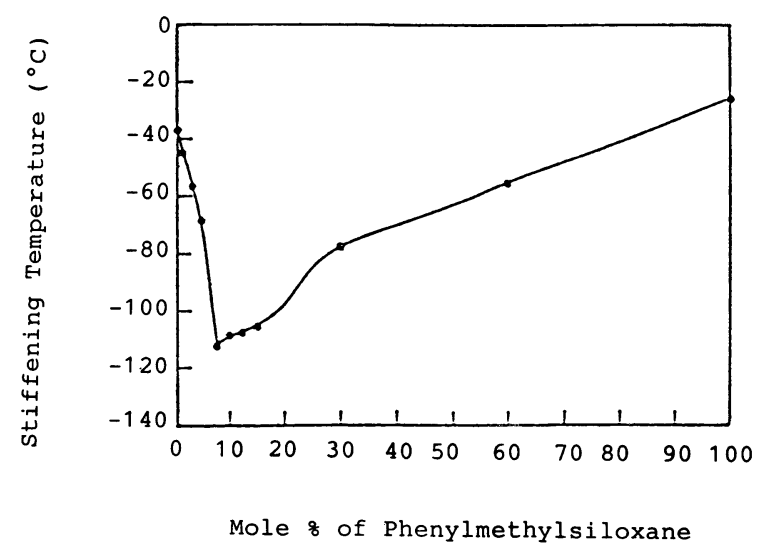

Fig. 4 Stiffening temperature as a function of molar content of phenylmethylsiloxane. ${ }^{3)}$ 


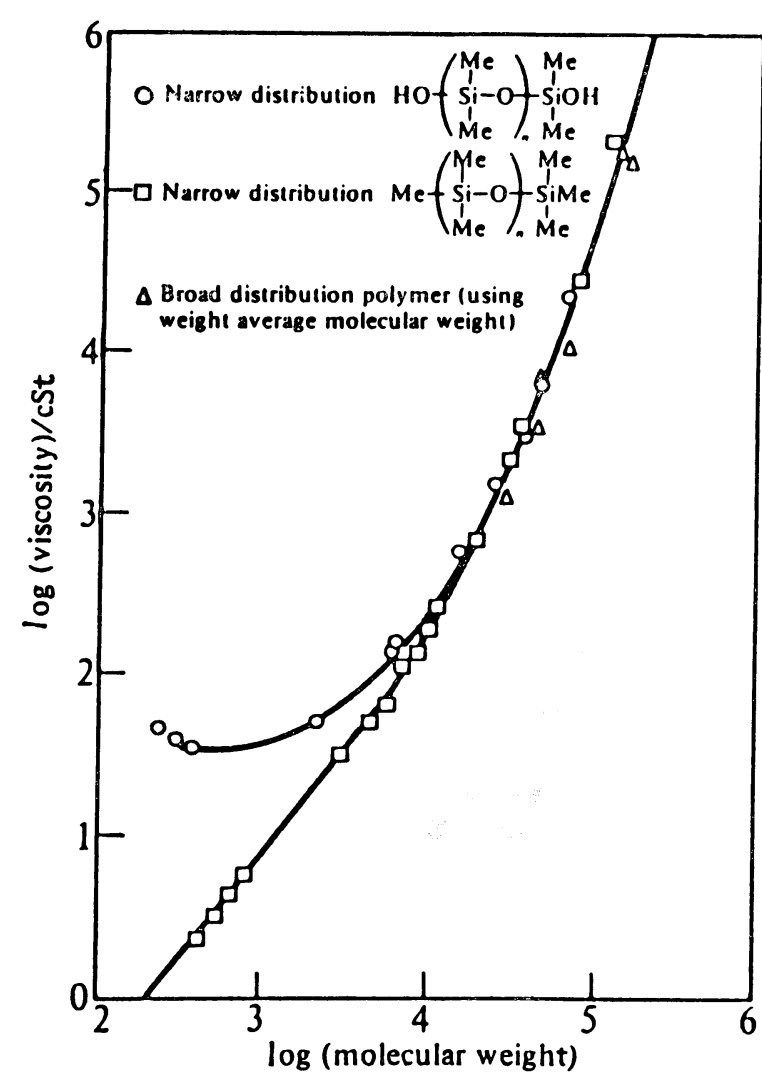

Fig. 5 Change in zero shear viscosity with molecular weight. ${ }^{\text {s) }}$

ピル，フェニル基と大きなものになるにつれ，粘度の温度依存性 は高くなり，流動の活性化エネルギーが大きくなると報告されて いる77. 低分子量のポリジメチルシロキサンは，広範囲の剪断領 域にわたってニュートン流体として振舞らが，高分子量になるに つれ非ニュートン性が影著となる。この挙動は平均分子量のみな らず, 分子量分布によっても変わり, 単分散に近いものほど, よ り高い剪断速度までニュートン性を保つ4) (Fig. 7). また当然, 有機基の種類によっても挙動は異なるが，この場合は有機基が大 きくなるにつれ，よりニュートン流体に近くなると報告されてい $ろ^{7)}$.

\section{3. シリコーンゴムのレオロジーに関する課題}

一ロにシシリコーンゴムと言っても，その形態は様々である.

ゴムの加工という観点から分類すれば, 高分子溶融体として取 り扱觉るポリマーのみからなる材料から, 各種充填㓮を配合した 分散系までを含む. 実際の加工機を考虑すれば，後者はポンプに よる圧送が可能な液状ゴムと，2本ロールに代表される高馬力の， いわゆるミリング装置によって可塑化や混合が行われるミラブル ゴムに分類される. 一方, 加工後の成形物の性状から見れば, 柔 軟で粘着感のある表面を有するゲル状物から, プラスチックに近 い硬度のゴムまでが広義には含まれるだろう. 架橋は加水分解性 官能基とシラノール基との縮合反応，ヒドロシリル化反応による 付加反応, または有機過酸化物により行われている. 液状ゴムで は, 分子量数万で末端にシラノール基やビニル基, 加水分解可能 な官能基を有するテレキレックポリマーが用いられるが， ミラブ ルゴムの場合は, 分子量数十万のガムと呼ばれるポリマーが使わ

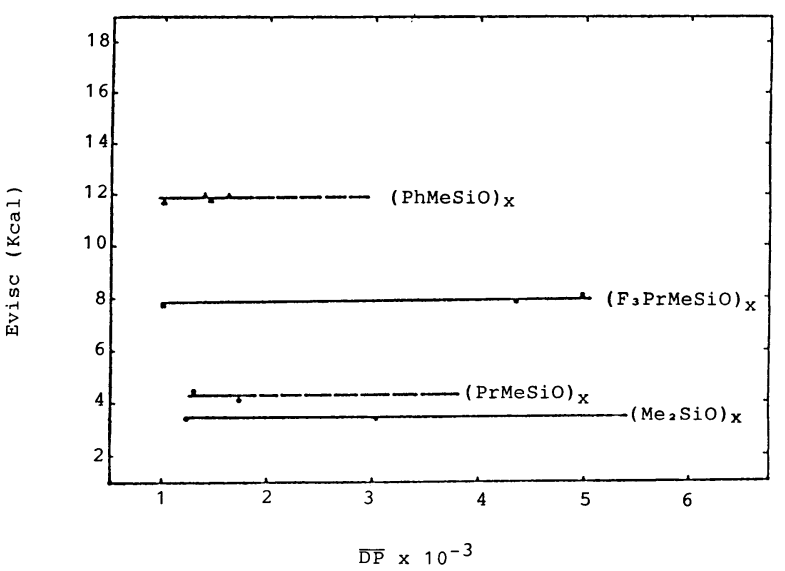

Fig. 6 Energy of activation for viscous flow vs. degree of polymerization. ${ }^{7)}$

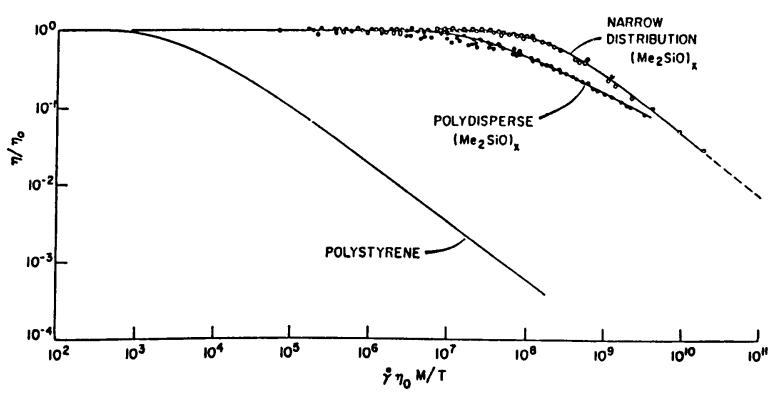

Fig. 7 Effect of molecular weight distribution on rate-dependent viscosity. ${ }^{4}$ )

れる. 充填刘としては種々のものが実用化されているが，特に物 理強度を要求される場合は, 表面活性の極めて高い微粉末状のシ リカが最も一般的に使用されている. 微粉末シリカを配合したシ リコーンゴム組成物の流動挙動は, 著しい非線形を示し解析が困 難なためか, あるいは, 有機系ゴム組成物と比較して一般には流 動性が良いので, それほど問題とされなかったためか, 充媜量の 少ない系での報告例 ${ }^{911)}$ 以外, 注とんど見当らない. 混合機や加 工機の設計に必要な機械強度, 動力等を推定するためのエンジニ アリングデータという意味の実用的観点から, 剪断速度一剪断応 力の測定例 ${ }^{12}$ はある. しかし, 材料の加工性, 成形性については 理論的解析はもちろん, 経験則による一般化もできないのが現状 である.

$3 \cdot 1$ シリコーンゲル

シリコーンゲルと呼ばれるー一連の製品群は, 電子・電気部品の 保護材として広く利用されているが, 最近, 電子部品の微細化に 伴い, 従来の防湿, 防塵とい5目的以外飞, 振動や熱ショックか らの保護が重要になりつつある。また, シリューンの各種物性の 温度依存性が小さいことに注目した, 防振部品への忘用も進めら れている．ゲルを区分する主たる特性は硬化物の柔軟性であるが， その測定法は規定されたものがなく, JISK 2220 (グリース), JISK 2207 (石油アスファルト) に規定される稠度，または針入 度試験法による測定值をもって表現されてきた. これらの測定值 は, 当然ながらゲルの動的特性や防振特性を反映したものではな く, 類似の柔軟性を持つゲルでも, 性能が顕著に異なる場合が多 い. 典型例を Fig. 8 と Table II に示した. シリコーンゲルは ポリマーのみからなる場合が多く, 従ってこの粘弾性の制御はポ 
Table II. Properties of silicone gel. Storage modulus and loss modulus were measured by a cone-pate rheometer at $1 \mathrm{~Hz} / 60^{\circ} \mathrm{C}$.

\begin{tabular}{cccccc}
\hline \multirow{2}{*}{ Sample } & \multicolumn{2}{c}{ Penetration } & \multicolumn{2}{c}{ Moduli } & $\left(\right.$ dyne $\left./ \mathrm{cm}^{2}\right)$ \\
& JIS K2220 & JIS K2207 & \multicolumn{6}{c}{$G^{\prime}$} & $G^{\prime \prime}$ \\
\hline 1 & 47 & 174 & 29,700 & 74,100 \\
2 & 46 & 150 & 1,140 & 29,700 \\
\hline
\end{tabular}

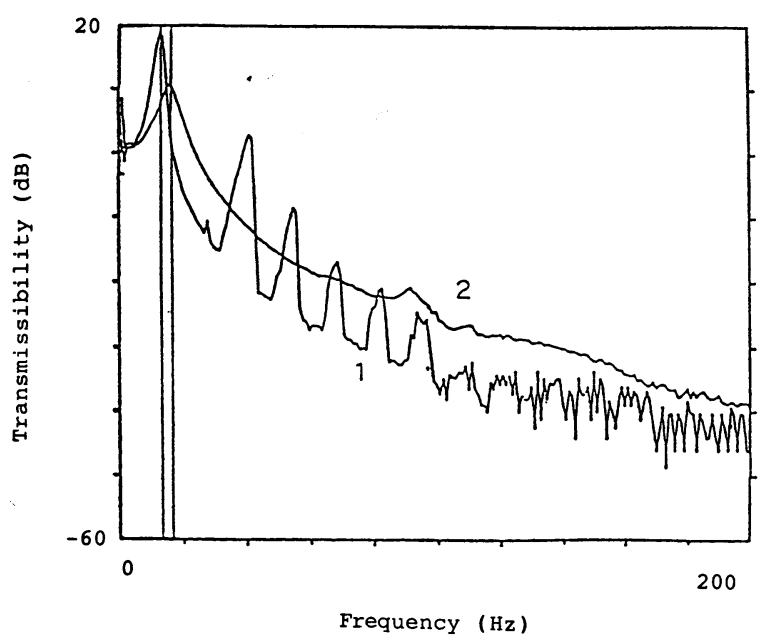

Fig. 8 Damping properties of silicone gel. 1 and 2 correspond to sample numbers in Table II.

リマー設計の問題であり，充媜系と比較し構造はより単純である と言えるが，まだ技術的にも理論的にも確立されて拉らず，今後 の研究課題となっている.

\section{$3 \cdot 2$ ミラブルシリコーンゴム}

ミラブルシリコーンゴムは有機系ゴムと同様に，2本ロールで 素練り, 混練を行った後, 压縮成形, 射出成形, トランスファー 成形, 押出成形等により成形加工される。このような一連の加工 作業での加工性の試験方法は, 規格化されたものが臣とんどな く, 現場に怙ける種々の問題や現象を予想するのは極めて困難で ある.

未硬化のシリコーンゴムの流動挙動は, 充填剤含有量や剪断領 域によって複雑に変化するが12)，一般的には擬塑性流動体と見な せる. 可塑性粘度の測定法としては, ウイリアムス可塑度計に代 表される压縮形, ムーニ一粘度計に代表される回転形, 拉よび押 出形可塑度計によるものがあり, 試料の受ける剪断速度はそれぞ れ $10^{-5} \sim 10^{-1}, 10^{-2} \sim 10$, 抢よび $10^{-1} \sim 10^{4}(1 / \mathrm{sec})$ の範囲にあ $る^{13)}$. JISK 6300 (未加硫ゴム物理試験方法) には，ムーニ一粘 度計执よびウイリアムス可塑度計による試験方法が規定されてい るが，シリコーンゴムでは後者が專ら採用されている．この方法 により得られる可塑度值は, 広範囲な剪断領域に打ける流動の複 雑な平均值であって，その物理的意味は必ずしも明確ではないが, 材料の大まかな流動性の目安とは成り得る. しかし, 未硬化のゴ ム材料は典型的な粘弾性体であり, 単一の作業機注いてさえ, そこでの加工性に対して重要なタイムスケールもしくは歪速度の 分布が極めて広範囲であることを考劣ると，いかなる可塑度計で あっても，それだけではいかにも不十分であると言わざるを得な いだろう。

Fig. 9，10 扣よび Fig. 11, 12 に示した例は, 重量平均分子量

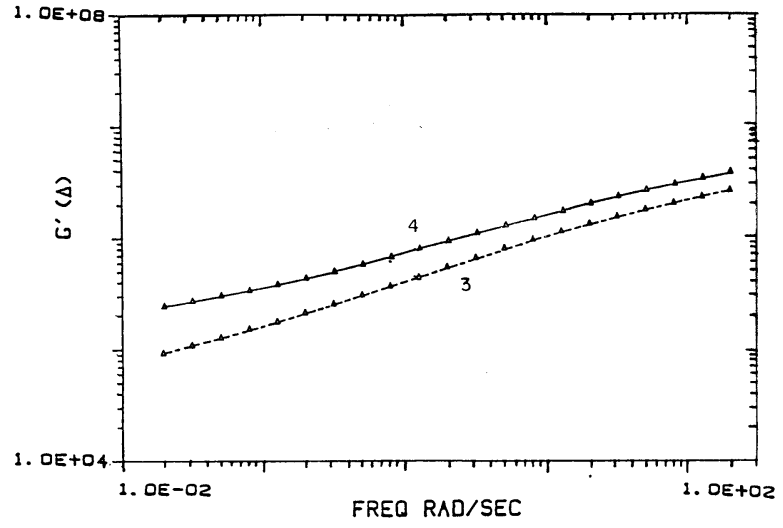

Fig. 9 Storage modulus of silicon rubber stocks measured by a parallel plate pheometer at $50^{\circ} \mathrm{C}$. Sample 3 shows better processability than sample 4 .

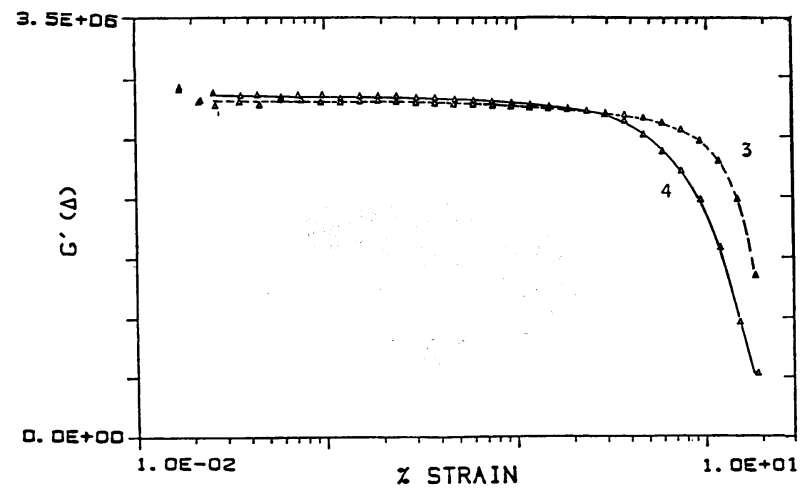

Fig. 10 Storage modulus of silicone rubber stocks as a function of strain at $10 \mathrm{~Hz} / 50^{\circ} \mathrm{C}$. 3 and 4 correspond to sample numbers in Fig. 9.

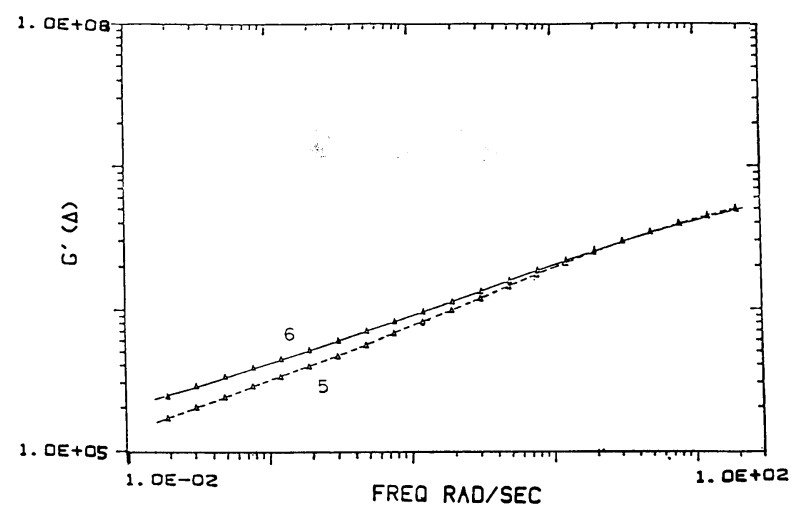

Fig. 11 Storage modulus of silicone rubber stocks measured at $50^{\circ} \mathrm{C}$. Sample 5 shows better processability than sample 6 .

が約50万のポリジメチルシロキサンガム 100 部に, 沈降シリカ40 部と，少量の可塑剤と添加剤を配合したシリコーンゴム組成体で， 化学組成上は同一と見なされるサンプルについて，動的粘弾性を 測定した結果である. 図中番号で示したサンプル№. 3 はN No. 4 より も, またNN. 5 はNNo 6 よりも実際の加工機で加工性が良好と判定さ れた. Fig. 9 拈よび Fig. 11 から，№.3 拈よびNo. 5 の方がそれ ぞれNNo. 4 扣よびNo. 6 よりる，貯蔵弾性率 $G^{\prime} か ゙$ 低周波数側へいくほ ぞ低下が顕著であり，いわゆる構造性が低いと見なされる。しか 


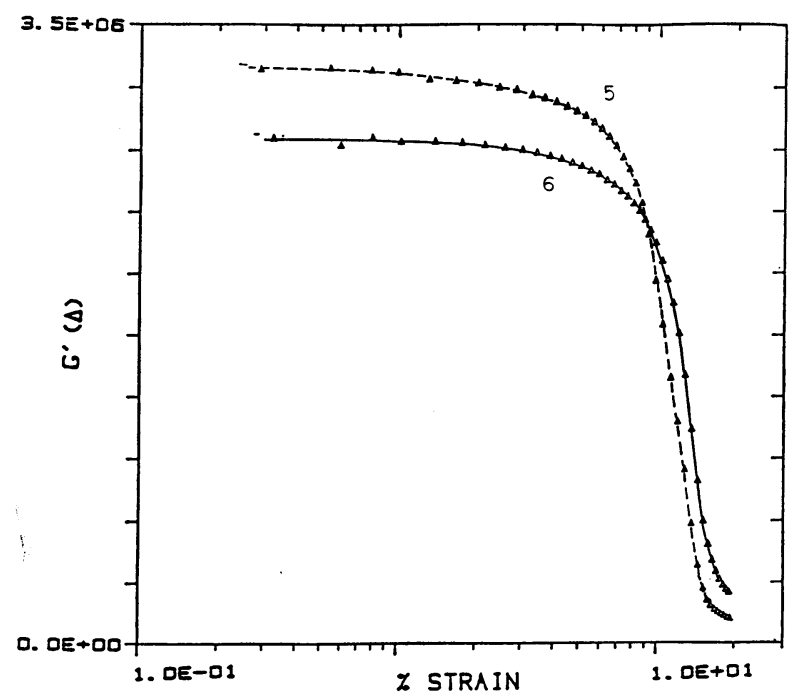

Fig. 12 Storage modulus of silicone rubber stocks as a function of strain at $10 \mathrm{~Hz} / 50^{\circ} \mathrm{C}$. 5 and 6 correspond to sample numbers in Fig. 11.

し，Fig. 10，12 の歪依存性を見ると，№. 3 はNNo. 4 よりも線形領 域が広いのに対し，№. 5 はNN.6 よりも逆に若干狭くなっている. すなわち，上記二つの例に和ける「構造性の差」は，その内容を 異にしていると考学られる。

シリコーンゴムも有機系ゴムと同様, ポリマー分散媒中に粒子 が単に分散した構造ではなく, 複雑な高次棒造を形成していると 考えられている。このようなゴムの構造は, 充埧剤表面に拘束さ れた相（バウンドラバー）によって特徴づけられている ${ }^{14), 15)}$. 更にシリコーンゴムに特有なレオロジー特性として, クレープ硬 化 (Crepe hardening) と呼ばれる貯蔵中の硬化現象がある。これ はバウンドラバーの増加と, その構造変化と密接な関嘲があり, 充填剤であるシリカの表面シラノール基が重要な役割を果たして いると言われている。

シリコーンゴムの場合, バウンドラバーの生成は物理的な構造 変化であるとの報告 ${ }^{16)}$ もるが，熱処理が施される場合にはシリ カ表面のシラノール基の活性から，化学反応の寄与も無視できな

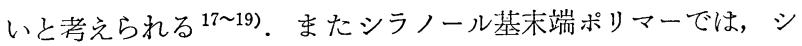
リカとの相互作用は非常に強くなり，クレープ硬化したゴムは過 酸化物により化学的に架橋したゴムに匹敷する物理強度を示す20). これらのことを考えると, 複合体としてのゴムのミクロ構造解析 が是非必要であると考えられる.

最近, バルス法NMRによりバウンドラバーの構造や生成機構 について解析が試みられている. 田中, 野村らは天然ゴムにカー ボンブラックを充填したゴム組成物のバウンドラバーの生成をこ の方法により解析し，バゥンドラバーは緩く拘束された相と，祭 密に拘束された相から成っていること，その生成はカーボンブラ ックの分散と平行して混練初期に急速に起こり, 混練の進行に伴 ってより緊密な棈造に变化して行くことを示した ${ }^{21)}$. また，ポリ イソプレン/シリカ充填系でも同様な解析を行い, バウンドラバ 一の生成, 構造にはシリカ表面シラノール基の答与が大きいこと を示した ${ }^{22), 23)}$. シリコーンゴムに対するこの種の研究は始めら れたばかりであり ${ }^{24)}$, 詳細な報告はまだ見当らない. しかしなが ら, 先に挙げた二つの例からも示されるように, ゴムの加工とい
万実用的見地からすれば、ゴムの高次構造と粘弾性挙動の関係を 明確にし、これを制御することは極めて重要であり，今後の研究 が待たれる課題と言える.

\section{文献}

1) Baney, R.H., Voigt, C.E., and Mentele, J.W., "StructureSolubility Relationships in Polymers”, ed. H. Seymour (1977), Academic Press, New York.

2) Falender, J., and Monroe, C.M., ACS Rubber Division Preprints, No. 6 (1973).

3) Polmanteer, K.E., and Hunter, M.J., J. Appl. Polym. Sci., 1(1), 3 (1959).

4) Lee, C.L., Polmanteer, K.E., and King, E.G., J. Polym. Sci., A-2, 8, 1909 (1970).

5) Wilkinson, G., Gordon, F., Stone, A., and Abel, E. W., "Comprehensive Organometallic Chemistry" (1982), Pergamon Press, New York.

6) LaRochelle, R.W., Cargioli, J.D., and Williams, E.A., Macromolecules, 9(1), 85 (1976).

7) Polmanteer, K.E., Elastoplastics, 2, July, 165 (1970).

8) Dill, T. J., Falender, J. R., and McHale, A.H., ACS Polym. Prepr.' 22(2), 403 (1981).

9) Cantu, T.S., Caruthers, J.M., J. Appl. Polym.Sci., 27, 3079 (1982).

10) Ziegelbaur, R.S., and Caruthers, J.M., J. Non-Nerotonian Fluid Mechanics, 17, 45 (1985).

11) Kosinski, L. E., and Caruthers, J. M., ibid., 17, 69 (1985).

12）中島 功, 有我 欣司, “けい素樹脂” (1970), 日刊工 業新聞社.

13）“ゴム試験法”(1980), 日本ゴム協会.

14) Cotten, G.R., Rubber Chem. Technol., 48, 548 (1975).

15) Southwart, D.W., Polymer, 17, Feb., 147 (1976).

16) Vondracek, P., and Schätz, M., J. Appl. Polym. Sci., 21, 3211 (1977).

17) Berrod, G., Vidal, A., Papirer, E., and Donnet, J.B., J. Appl. Polym. Sci., 26, 833 (1981).

18) idem, ibid, 26, 1015 (1981).

19) Li Yu-fu, Xia Yong-xia, Xu Dong-peng, and Li Guangliang, J. Polym. Sci., Polym. Chem. Ed., 19, 3069 (1981).

20) Boonstra, B. B., H. Cochrane, H., and Dannenberg, E.M., Rubber Chem. Technol., 48, 558 (1975).

21) Serizawa, H., Ito, M., Kanamoto, T., Tanaka, K., and Nomura, A., Polym. J., 14(2), 149 (1982).

22) Ito, M., Nakamura, T., and Tanaka, K., J. Appl. Polym. Sci., 30(8), 3493 (1985).

23）伊藤 真義, 中村 武房, 田中 公二, 日本ゴム協会誌, 58(7), 468 (1985).

24) Tanaka, H., Yukawa, H., Fujita, S., Nishi, T., and Hyodo, S., Rept. Progr. Polym. Phys. Japan, 27, 549 (1984). 